\title{
顎顔面骨の3次元的形態再現に関する研究
}

\author{
第了報：パーソナルコンピュータによる画像再現（D I M 3）
}

三原学

\section{Studies on three-dimensional reproduction of maxillofacial crunium shape \\ 3. Personal computer graphics image (DIM 3)}

\author{
Manabu MiharA
}

\begin{abstract}
The three-dimensional personal computer graphics (DIM 3) was developed by the autheor.

Input data were traced out of the maxillofacial cranium shape of the CT films by the cursor pen on the digitizer, and the computer graphics image was reproduced on the CRT and X-Y plotter.

The reproducible accuracy of the graphics was satisfactory for use in diagnosis, surgical therapy planning and morphological studies in the field of maxillofacial surgery.
\end{abstract}

Key words: Three-dimensional reproduction, computer graphics, maxillofacial cranium shape

\section{I. 緒言}

著者はこれまで, 罘顔面骨の 3 次元的形態再現につい $\tau, \mathrm{X}$ 線写真や Computed tomography (CT) を資料 として, 模型再現による 3 次元形態再現法を考案, 報告 してきた ${ }^{1 \sim 2)}$. 模型による形態再現は，病状の形態把握 や移植物および義龥の設計や手術計画などに，ただちに 臨床応用が可能で，実体として手にすることができ，実 際臨床で有用な点が多い，しかし一方で，資料として分 析検討するには，模型作製に要する労力や手技的詋差も 無視できない問題と思われる。本編では, これまでの研 究過程やその結果を応用し, パーソナルコンピュータに よる画像再現を試みたところ，有用な所見が得られたの で報告する。

\section{II. 使 用 機 器}

本研究に使用した機器を以下に示した。

1) NEC PC-8801 ハーソナルコンピュータ

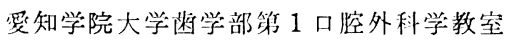

(主任：深谷昌彦教授)

First Department of Oro-Maxillo-Facial Surgery, School of Dentistry, Aichi-Gakuin University

(Chief. Prof. Masahiko Fukaya)

受付日：炤和59年11月26日
2) $\mathrm{NEC} \mathrm{PC-8881} \mathrm{ディスクューット}$

3) $\mathrm{NEC} \mathrm{PC-8852} \mathrm{カラーディスブレィ}$

4) $\mathrm{NEC} \mathrm{PC-8822} \mathrm{ドットマトリックスプリンター}$

5 ) オスコン グラフィックデジタイザーモデル $\mathrm{AC}-10$

6) グラディモート RS $232 \mathrm{C}$ アダプター

7 ) 岩通 SR-6602 パーソナルブロッター

\section{III. プログラム}

表 1 に, 考案, 作製した顎顔面骨 3 次元画像システム DIM 3 のプログラムを示した.

\section{IV. 資料}

資料は本研究第 2 報 2 )で行った CT の実験結果より, $\mathrm{GE}$ 製 $\mathrm{CTT}(8800, \mathrm{X} 2$ ) 第 3 世代 CT スキャナーに $\tau, \quad F O P=25 \mathrm{~cm}$, 管電圧 $120 \mathrm{kV}, 320 \mathrm{~mA}, 2.2 \mathrm{msec}$ (pulse x-ray) 下にて，スライス幅 $5 \mathrm{~mm}, 1$ スキャン 時間 $9.6 \mathrm{msec}, 1.8$ 倍した high resolutional program による骨 target 像により, Window Width 1,200 , Window Level 1,000 とし, Grid を描記させ, マルチフ オーマットカメラの density 650 で, 半切大 CT フィ ルムに 4 分割で再現した CTフィルム画像を原則として 用いた。 
表 1 DIM 3 のプログラム

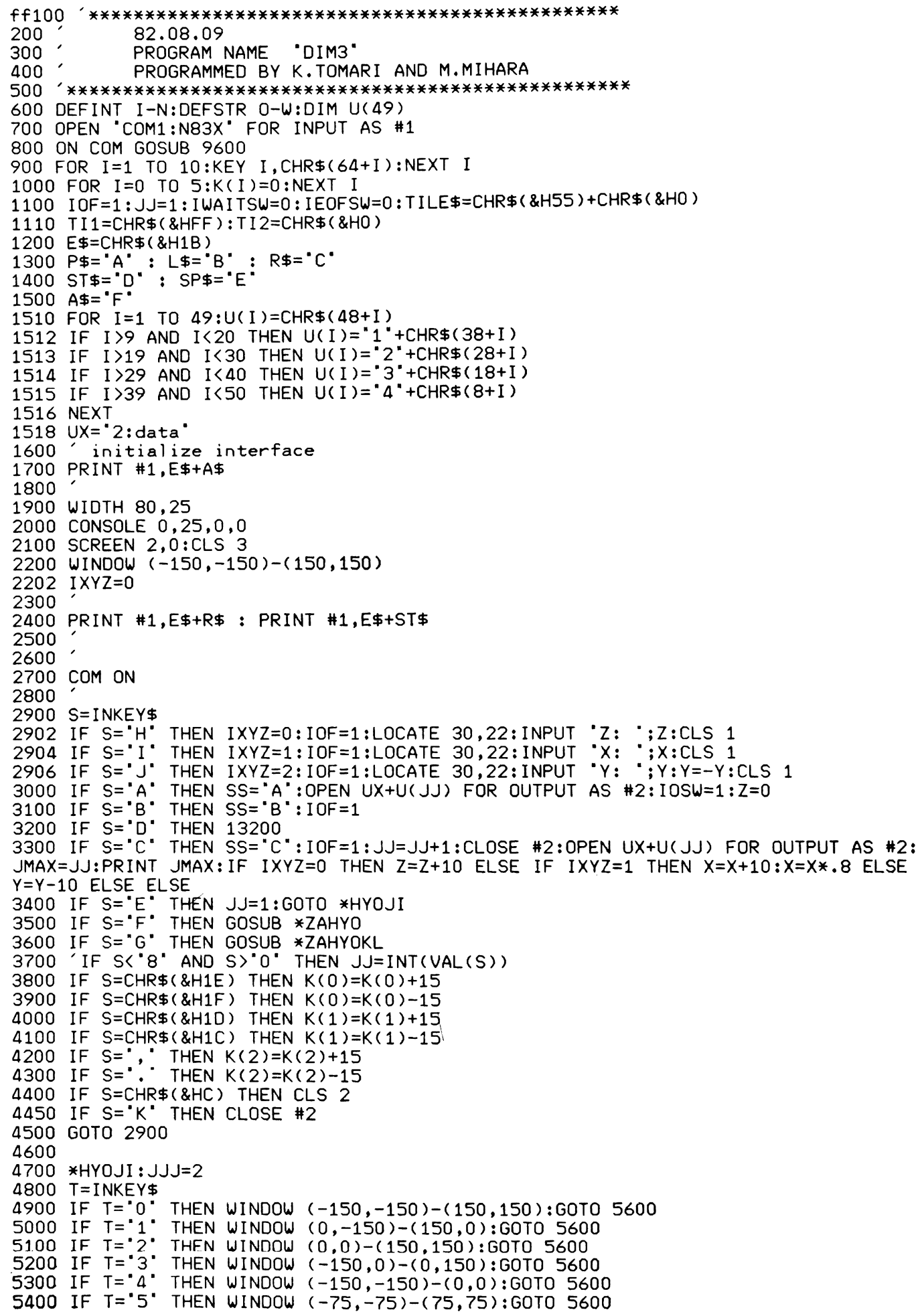


(表 1 つづき)

5500 GOTO 4800

5600 IO $=1$

5700 IF IOSW=1 THEN CLOSE \#2:OPEN '2:data0" FOR OUTPUT AS \#2: WRITE \#2, JMAX:CLOSE $\# 2:$ IOSW $=0$

5750 OPEN "2:dataO" FOR INPUT AS \#2: INPUT \#2, JMAX:CLOSE \#2

5800 OPEN UX+U(JJ) FOR INPUT AS \#2

5900 IF $K(0)=0$ AND $K(1)=0$ AND $K(2)=0$ THEN $*$ HYOJI2

$6000 A R=K(0) *(3.14159 / 4) / 45: A S X=S I N(A R): A C X=\operatorname{COS}(A R)$

$6100 A R=K(1) *(3.14159 / 4) / 45: A S Y=S I N(A R): A C Y=\operatorname{COS}(A R)$

$6200 A R=K(2) *(3.14159 / 4) / 45: A S Z=S I N(A R): A C Z=\operatorname{COS}(A R)$

6300 IF EOF(2) THEN IF JMAX =JJ THEN IEOFSW=1:GOTO 6700 ELSE CLOSE \#2:IWAITSW=1:G OTO 6700 ELSE INPUT $\# 2, X, Y, Z, K A, J X:$ GOTO 7400

6700 T=INKEY\$

6800 IF $T={ }^{\circ} L "$ THEN KKK $=1: X W 3=X: Y W 3=Y$

6900 IF $T=\cdot K \cdot$ THEN KKK $=0: X W 3=X: Y W 3=Y$

7000 IF $T={ }^{*} P \cdot$ THEN PAINT $(X W 2, Y W 2), T$ ILE $\$, 1$

7100 IF T=" $S$ " THEN IF IEOFSW=1 THEN IEOFSW $=0:$ CLOSE \#2:GOTO 2900 ELSE JJ=JJ+1:OPE $N U X+U(J J)$ FOR INPUT AS \#2:GOTO 6300

7200 IF $T=0^{\circ} 0^{\circ}$ "THEN LINE (XW3,YW3)-(XW2, YW2), KKK

7210 IF $T=" M "$ THEN LOCATE 77,24:INPUT JW:CLS 1:OPEN UX+U(JW) FOR INPUT AS \#2:GOS UB $*$ MHYOJI

7220 IF $T=" C "$ THEN PAINT(XW2, YW2), TI 1,1, TILE\$:PAINT(XW2, YW2), TI 2, 0, TI1

7300 GOTO 6700

7400 GOSUB *HYOJI3

8200 GOTO 6300

8300

$8400 *$ HYOJI1

8500 IF IO=1 OR KA=1 $\operatorname{THEN} \operatorname{PSET}(X, Y), 1: I O=0: \operatorname{RETURN}$

8600 IF IO=0 THEN LINE $-(X, Y), 1$

8700 RETURN

8800

$8900 *$ HYOJI2

9000 IF EOF (2) THEN CLOSE \#2:GOTO 2900

9100 INPUT $\# 2, X, Y, Z, K A, J J$

$9200 X=X+K(3): Y=Y+K(4): Z=Z+K(5)$

9300 GOSUB *HYOJI1

9400 GOTO 9000

9500

9600 COM OFF

9700 IF IWAITSW=1 THEN PRINT \#1,E\$+P\$:GOTO 9900

9800 PRINT \#1,E\$+R\$:PRINT \#1,E\$+ST\$

9900 PRINT \#1,E\$+SP\$

$10000 X W 1=X: Y W 1=Y:$ INPUT $\# 1, X \$:$ INPUT $\# 1, Y \$$

$10100 B X=(\operatorname{VAL}(X \$) / 10)-150: B Y=(\operatorname{VAL}(Y \$) / 10)-150$

$10200 B X=B X * 1 \cdot 23: B Y=-B Y * 2$

10300 IF IWAITSW=0 THEN 11000

$10350 \quad X=B X: Y=B Y$

$10400 X W 2=X: Y W 2=Y$

10500 IF POINT $(\operatorname{MAP}(X, 0), \operatorname{MAP}(Y, 1))=0$ THEN LL=1:LLL=0 ELSE LL=0:LLL=1

10600 PSET $(X, Y), L L$

10700 FOR II $=0$ TO $300:$ NEXT II

10800 PSET $(X, Y)$, LLL

10900 GOTO 11400

11000 IF (SS $=" A$ " OR SS=" $B$ " OR $S S={ }^{\circ} C$ ") AND IXYZ=1 THEN $Y=-B X * 1.55: Z=-B Y$

11001 IF ( $S S={ }^{\circ} A$ " OR $S S={ }^{\circ} B$ " OR $S S={ }^{\circ} C^{\prime}$ ) AND I $X Y Z=2$ THEN $Z=B X * 1.6: X=-B Y * .6$

11002 IF ( $S S={ }^{\circ} A$ " OR $S S={ }^{\circ} B{ }^{\circ}$ OR $S S={ }^{\circ} C^{\circ}$ ) AND IXYZ=0 THEN $X=B X: Y=B Y$

11010 IF $S S={ }^{\circ} A$ " OR $S S={ }^{\circ} B$ " OR $S S={ }^{\circ} C$ " THEN WRITE $\# 2, X, Y, Z, I O F, J J$

11100 IF IOF=1 THEN PSET $(X, Y): I O F=0:$ GOTO 11300

$11200 \operatorname{LINE}(M, N)-(X, Y), 1$

$11300 \quad M=X$ : $N=Y$

$11400 \quad A=\operatorname{LOF}(1)$

11500 IF $A<255$ THEN 10000

11600 PRINT \#1,E\$+ST\$

11700 COM ON : RETURN

11800

$11900 * \mathrm{ZAHYO}$

12000 LINE $(0,-150)-(0,150)$

12100 LINE $(-150,0)-(150,0)$

12200 FOR $L=-260$ TO 200 STEP 13:CIRCLE $(L, 0), .4:$ NEXT 
（表 1 つづき）

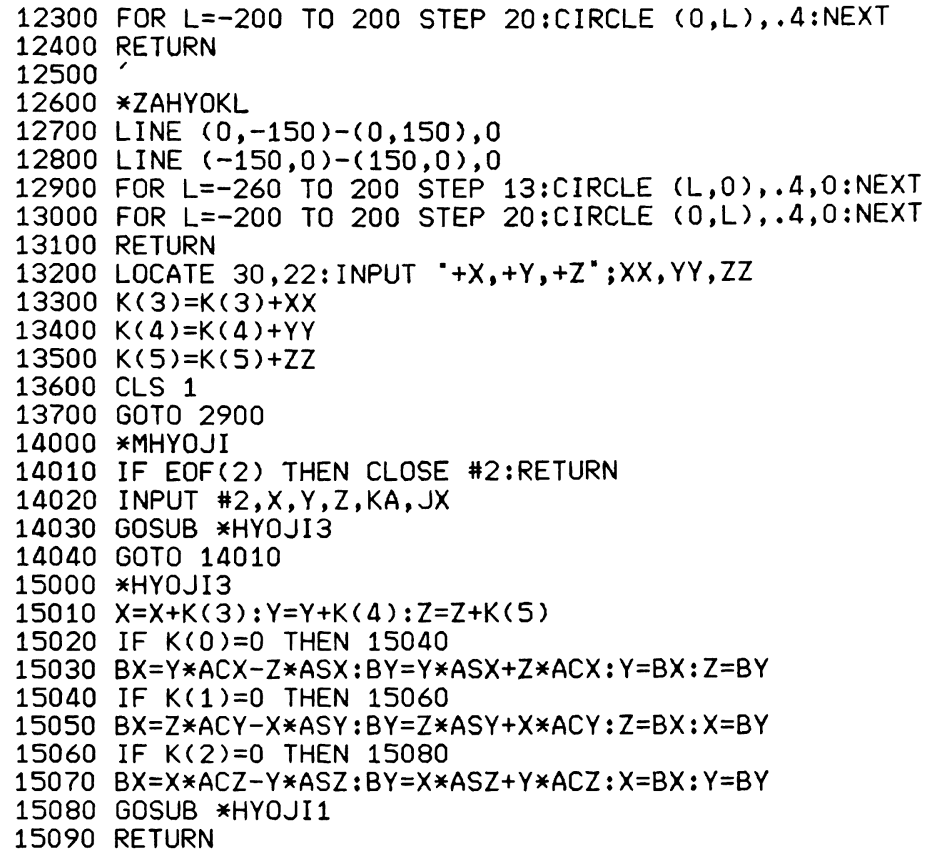

\section{V. 操 作 方 法}

資料とした CT フィルムもしくは，その買顔面骨形態 をトレースしたものを, デジタイザー上の直交巫標軸と CT 像に打ける Grid の直交座幖軹を重ね，セロテープ で固定し，スライスごとに順次，䫇顔面骨形態をカーソ ルペンでゆっくりトレースし入力した。

操作方法を以下に示した。

\section{1. 準 備}

1) ディスク,ディスブレイおよびデジタイザーの電 源を on にする。

2) ディスクのドライブ1にブログラムファイルをセ ット、ドライブ 2 にデータ用ディスケットをセットす る.

3) 本体の電源を on にする。

4) How many files (0-15)? が表示されたら，キー ボードより 2 のと打ち込む.

5）キーボードより RUN “DIM 3” と打ち込む.

2. 入力

1)キーボードよりAと打ち込む.

2) $\mathrm{x}, \mathrm{y}$ 平面で入力するには $\mathrm{H}$ と打ち， $\mathrm{z}$ 夾標の初 期值を入力する. $\mathrm{y}, \mathrm{z}$ 平面で入力するには I と打ち, $\mathrm{x}$ 夾䧣の初期倠を入力する。 $\mathrm{z}, \mathrm{x}$ 平面で入力するには $\mathrm{J}$ と打ち，y夾標の初期檤を入力する。
3) 同一スライス平面上で，2つ以上の閉図形が存在 するときは, 1 つの閉図形トレース後, キーボードBを 打ち込む.

4) 次のスライス平面に移る際に（座標平面を変える ときも）キーボードCを打ち込む.

5) データの人力の終りはKを打ち込む.

6） $\mathrm{x}, \mathrm{y}, \mathrm{z}$ 方向に平行移動させたいときは，Dを打 つことにより画面に $+\mathrm{x},+\mathrm{y},+\mathrm{z}$ と表示されるので, $\mathrm{x}$, $\mathrm{y}, \mathrm{z}$ について数倬を入力しいを打つと平行移動する.

\section{3. 入カしたデータの表示}

1）入力したデータを認意に回転させたいときは， † を打つと $\mathrm{x}$ 軸に対し $15^{\circ}$ 回転, 」を打つと $\mathrm{x}$ 軸に対し $-15^{\circ}$ 回転, 七を打つとy 軸に対し $15^{\circ}$ 回転, ↔を打つ と $\mathrm{y}$ 杣に対し $-15^{\circ}$ 回転, ，を打つと $\mathrm{z}$ 糨に対し $15^{\circ}$ 回 転，を打つと $\mathrm{z}$ 軸に対し $-15^{\circ}$ それぞれ回転する。

2 ）表在表示されている図形を消したいときは鸟CL を打つ.

3 ）表示させるには, キーボードEを打つ.

4 ）通常象限で表示させたいなら 0 を入力. 第 1 象限 のみ表示させたいなら 1 を, 第 2 象限のみを表示させた いなら 2 を，第 3 象限のみを表示させたいなら 3 を，第 4 象限のみを表示させたいなら 4 を，中央部のみを表示 させたいなら5を入力する。

5）1つのスライス平面を表示させたら，作図は一時 停止する。このとき以下の入力が可能である。 Lは線の 
描記，Kは線の消去を可能とし，̄は線を画面に引いた り消したりする，すなわち，几を押して oをを押すか， Kを押してうを押す。 P は線で囲をれた部分をペイン トし，Cはペイント部を消去する．ただ， L， K， o, $\mathrm{P}, \mathrm{C}$ はデジタイザー上にてカーソルペンにて入力す る。 M は指定したスライス面を再度表示させることが できる。

6）トレースした図形の，次へのスライス面の表示に はSを打つ．Sを続けて打ち込むことにより最後のスラ イス面まで結けて表示される。

7) 直交座標軸を画面に表示するにはFを入力し， G を入力することにより直交座標軸は消去する。

\section{VI. 再 現 画 像}

\section{1. 乾燥頭蓋骨の再現画像}

乾燥頭蓋骨を，先に述べた条件でェアスキャンした CT 写真を資料とし，DIM 3 によるバーソナルコンピ ュータ函像再現を行った．写真 1 K axial CT 資料と した再現画像，写真 2 K coronal CT を資料とした再 現画像を示した，また，axial CT およびそれに直交す る coronal CT を資料とし， scout view にて揌記され たスライスラインを規準として，それぞれを平行移動し て再現した画像を写真了に示した。

これら再現画像について検討すると， axial CT およ びそれに直交する coronal CT を資料とした画像が， 3 次元的なイメージや形態計測について優れていると思 われた。 しかし, axial CT もしくは coronal CT 単独

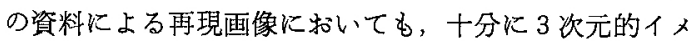
一ジが満たされており，両者を比較すると， coronal CT を資料とした再現画像がよく買顔面骨形態を再現してお り，形態計测に耐光うるものとみられた。

\section{2. 臨床応用}

臨州的には生体に対し，直交し合う axial CT 招よび coronal CT をスキャンすることは困難な場合が多い． このことから，任意の方向にスキャンした axial CT お よび coronal CT の交わる角度を正侧 2 方向の scout view より算出し，一方のスライス面を触变換（回転） させて画像再現する方法を倹討したところ，それぞれの 撮影 positioning の変換の際に，規準となる俥の複䊒な 3 次元的ずれが生し，その補正は必ずしも容易でなく， 放射線被嚗量の問題了, を加味し，さらに検討を重ねる 必要があると思われ，axial CT 括よび coronal CT 2 万向よりの資料による再現は今回は見合わせた。

写真 4 は左下靧骨エナメル上皮腫の coronal CT を資 料とした再琴画像で，任意の回転を与竞，骨形態の3 次 元的イメージを把握でき，XYプロッター上り認意の方 向から形態計測が可能で有用と思われた。

写真 5 は左上䂓癌切除, 放射線治療後 10 年を経過し,

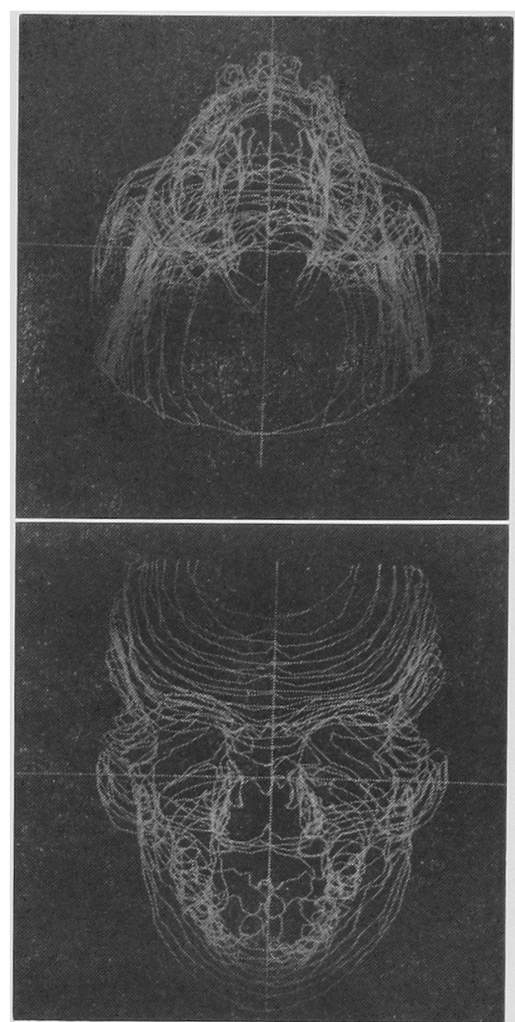

写真 1 axial CT を資料とした再現画像 (乾燥頭蓋骨)

煩骨に放射線性顎骨骨髄炎を発症した症例で，頓骨部の 分灕した腐骨除去後の coronal CT を資料とした再現画 像で，通常のX線写真战よび CT 読影のみでは困難であ った，残留した分樵腐骨の 3 次元的形態イヘージが得ら れた。

これらのことからも, DIM 3 によるコンピュータ画 像再現は臨休的にきわめて有用と思われた。な抏，臨林 応用に战ける詳細な倹討は後の機会に報告する。

\section{VII. 考}

察

これまで，生体の䫈顔面骨形態については頭部X線規 格写真などの 2 次元的資料をもとに，䠘床的検討や基儊 的研究が重视られ，多くの知見を供給してきたが，3次 元的罘顔面骨を 2 次元的資料で論ずるには，何かと不都 合を生じてきたのが現状と思われる。

近年, 種々の医用機器の開発も相まって, とくに医用 画像を用いて，生体の 3 次元的立体表示が大きなテーマ となっている. 現在では Mayo clinic の Dynamic spatial reconstruction (D.S.R.) が最も進んだ再現装置々 され，CT を数十台組み合わせた形式で，28本のX線管 


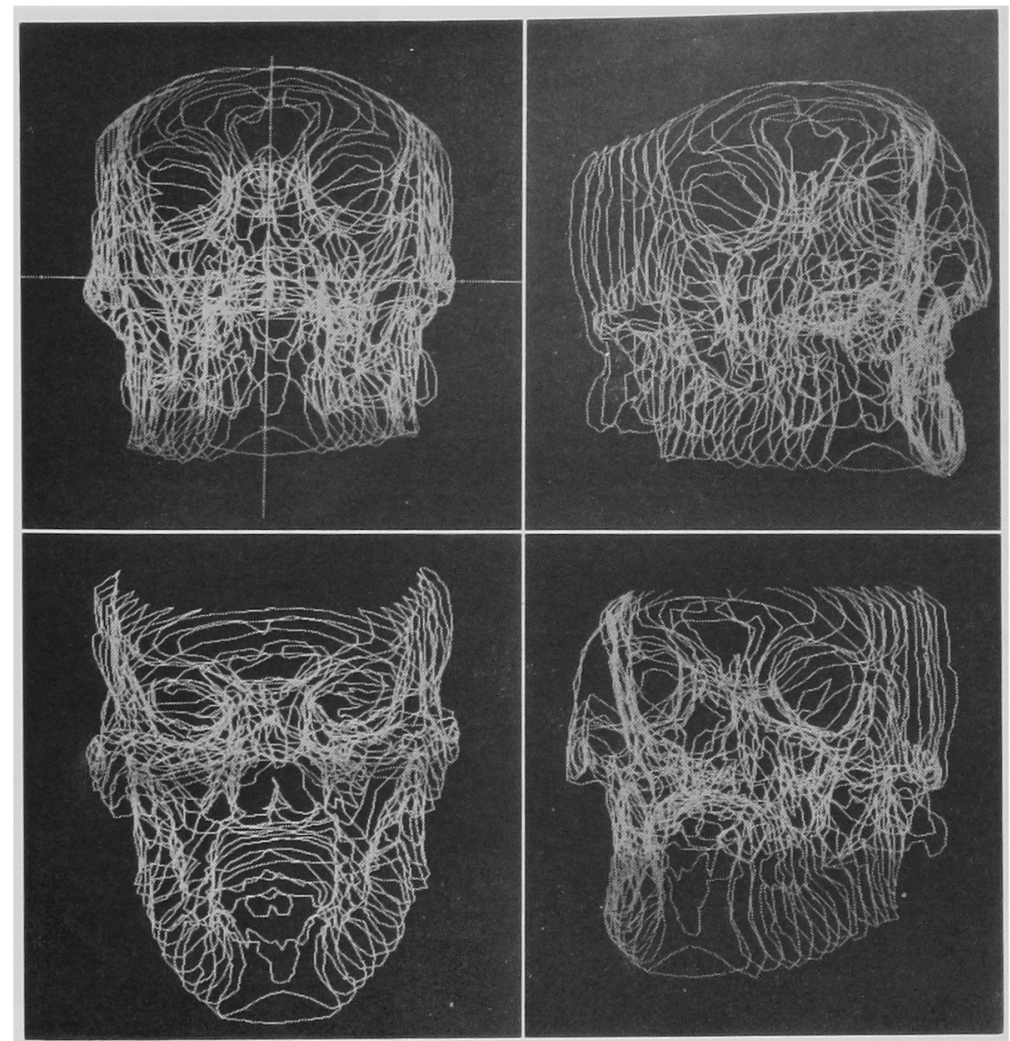

写真 2 coronal CT を資料とした再現画像（乾燥頭蓋骨）

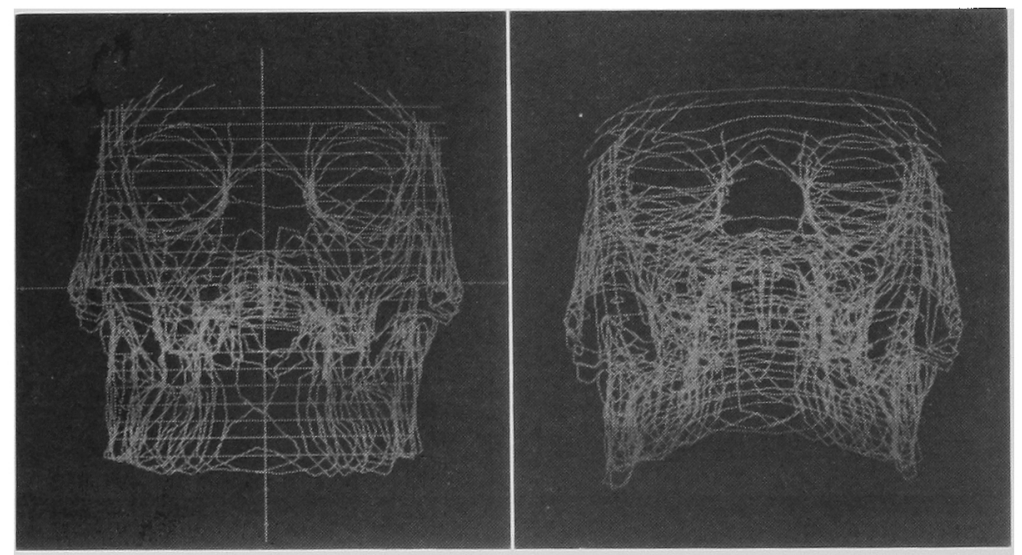

写真 3 axial CT そそれに直交する coronal CT を資料とした再現画像 (乾煰頭盍骨)

球の円弧状に配列させた装置を用いてスキャンし，これ をコンピュータで合成し，CT の画素よりもはるかに㯪 れた映像を立体的に観察する装置が完成している5，し かしこの装固はあまりにも高価で，分析に 1 週間を要 し，放射線被曝量も多いことから臨休使用には至ってい

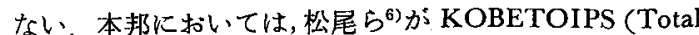
Image Processing System) を用いて, 種々の医用画像, とくにCTを処理し，3 次元構筑と 3 次元表示 CRT K よる 3 次元立体表示を行い，診断や放射線治療の照射野 設定に用いており，本研究分野における先駆的立場にあ 


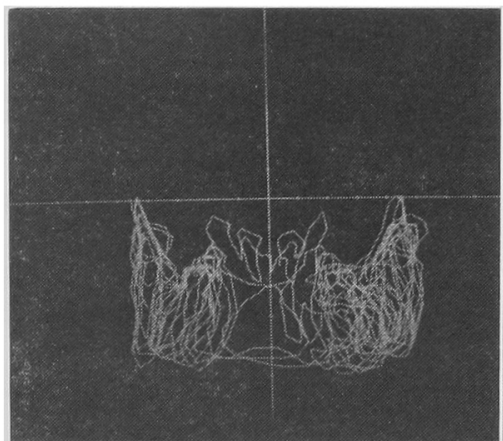

A：正面

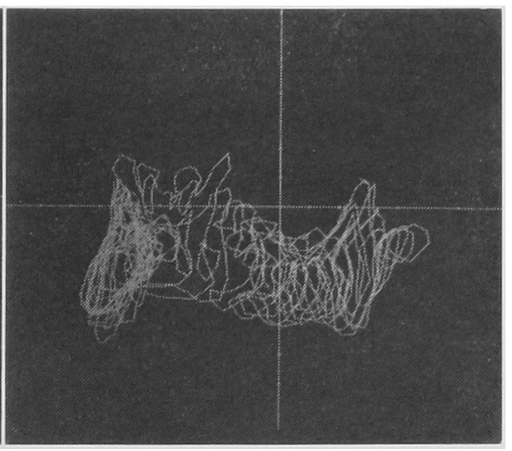

B：後方面

写真 4 左下顎骨エナィル上皮腫症例の coronal CT を資料とした再現画像

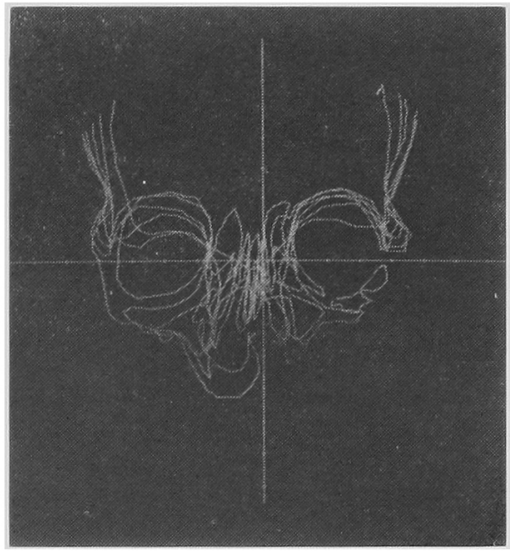

写真 5 左煩骨部の放射線性骨䯣炎症 例の coronal CT を資料とし た再現画像。左煩骨部に分離 した㦄骨が再現されている。

ると思われる。また，丸茂つは下頻骨の断層摱影写真を 大型コンピュータにより図形解析処理システムを用い,

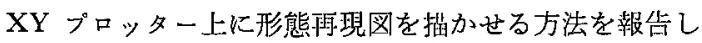
ている。

著者は，顎顔面骨の3 次元的形態再現について，これ まで模型による再現方法を報告してきだ〜2) 3 次元的 形態再現法の理想は，即座に入取可能な精密再現模型で あるが，検㣙の結果，儖床的要求精度をほ医淦たするの の，学力や手技的䛊差を現状では舆視できない，そこ で，資料として分析するに有利なコンピュータ画像丽現 を行った。

現在 computer graphics の医学利用自体が，また発展 途上のため，今後どのよらな利用法が開発されるか予测 は困難とされている8 ，また再現精度や入力方法，とり わけ経賃を無視すれば、コンピュータによる靧顔面骨の 3 次元的画像再現は理論的に可能とされている，留意す べきは，臨床や研究の場に即した再現方法で，要求を漰
たするのでなけ机ばならない 近年，パーソナルコンピ ュータの普及忙目覚しく，機能的にも10年ほど前の大型 コンピュータと損色のない面も具借してきており，それ ぞれの教室や㼋究室でパーソナルコンピュータを用い, 著者の考案したソフトウェア DIM 3 を使用し，検討す ることは比較的容易なるのと思小れる。ささらにニーズに 応じたソフトウェアの改良, 添加が重ねられれば幸いで

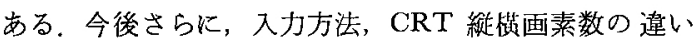
による函像の歪み，3次元的画像に対する視点の設定, 形態計測の自動化, 再現性の向上などについて, 検討を 進める必要があると考えている.

\section{VIII、結}

\section{語}

CT 写真を資料として，デジタイザー上でトレースし 入力,パーソナルコンピュータによる䫈顔面骨の3 次元 的画像再現を，作製したプログラムDIM 3 にて実施し たところ, 再現性は，乾燥頭蓋骨および臨床応用例につ いても皃满足のゆくめのであった，今後さらに，入力 方法や再兒性の向上について，検討を進める必要性もあ ると考えられた。

稿を終えるにあたり，終始ご留篤なるご指導ご枍閲を 赐った教室主任深谷昌彦教授に樑く感謝いたします。ま たここ協力ご援助いたたきました本学第 1 口腔外科学教 空各位に感謝の密袁します。ささらにプログラム作製に

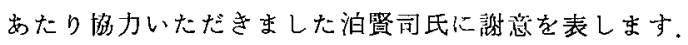

本論文の要旨は，炤和58年第37回日本口腔科学会総会 (於：大阪)，㗁和59年第19回日本形成外科学会中部地力 会にて発表した。な扣本矿究は，交部省利学研究韭の助 成を受けて行われた。

\section{引用文献}

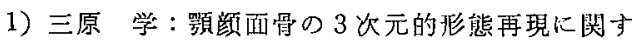


る研究 第 1 報: 下顎骨形態再現模型の 1 作製 法. 日口外誌 29: 1363-1369 1983.

2) 三原 学: 顎顔面骨の 3 次元的形態再現に関与 万研究 第 2 報: Computed tomography (CT) 在応用した再現模型。日口外誌 30：1304-1311 1984.

3) McCullough E.C. and Payne, J.T.: Patient dosage in computed tomography Radiology 129: 463-475 1978.

4) 真野 勇, 金子昌生, 他：Computed Tomography 装置の基礎的研究 (第 8 報) 一一頭部撮 影に扣外被嚗線量（8機種について）一. 日
本医放会誌 39：528-535 1979 .

5）池田茂人：医学に批方三次元立体像としての ホロクラフィーについて。胦像情報メディカル 15: 2731983.

6) 松尾導昌, 藤彗進, 他: CT 画像の 3 次元立 体表示システムの開発。㭥像情報入ディカル 11: 465-475 1979.

7）丸茂一郎：断層撮影に上る下顎骨骨体の立体的 再現法。日口外誌 22：605-623 1976.

8) 松尾導昌, 杉村和朗：喉頭拉よび Computer Graphics のホルグラム。映像情報メディカル 15: 254-255 1983. 